\title{
Présentation de Claude Simon
}

\section{Patrick Longuet}

\section{(2) OpenEdition}

Journals

Édition électronique

URL : http://journals.openedition.org/ccs/574

DOI : $10.4000 /$ ccs. 574

ISSN : 2558-782X

\section{Éditeur :}

Presses universitaires de Rennes, Association des lecteurs de Claude Simon

\section{Édition imprimée}

Date de publication : 30 avril 2007

Pagination : 127-130

ISBN : 9782354120122

ISSN : 1774-9425

\section{Référence électronique}

Patrick Longuet, «Présentation de Claude Simon », Cahiers Claude Simon [En ligne], 3 | 2007, mis en ligne le 21 septembre 2017, consulté le 04 mai 2019. URL : http://journals.openedition.org/ccs/574 DOI : $10.4000 /$ ccs. 574 


\section{Archives}



Claude Simon a toujours entretenu avec la littérature un rapport réfléchi. Plus largement, dès son expérience malheureuse de la peinture, il s'informe d'un savoir possible de l'art (les théories d'André Lhôte sur les complémentaires), avant de rechercher chez Valéry ou même Cocteau, plus tard Borges, les fragments d'une connaissance de la littérature inévitablement déçue. Qu'un philosophe écrive Qu'est-ce que la littérature ? en 1947 et qu'il s'agisse de Sartre, engage immédiatement au débat. Presque immédiatement : dix ans ont passé quand Claude Simon rédige un texte polémique qu'il conserve dans ses tiroirs. L'air du temps inciterait-il à polémiquer même dans le secret de l'atelier? Sur quoi porte l'affrontement ? Principalement sur la relation de l'œuvre et de ses lecteurs sous l'angle du milieu social de ces derniers. On écrit pour le peuple et cela suppose un souci d'utilité affirme Sartre. Fadaises pour Claude Simon qui n'admet pas de littérature assujettie à cet utilitarisme. L'utilité littéraire serait d'un autre ordre et n'a jamais touché que des lecteurs avertis, socialement privilégiés. Et les lecteurs de Sartre ne font pas exception ironise-t-il encore.

Pourtant la relation de la littérature au peuple intéresse les deux hommes : sous la forme d'un discours pour Sartre, sous celle de longues descriptions pour Claude Simon. Tous deux écrivent pour le peuple, soit pour contribuer à son affranchissement des contraintes politiques, idéologiques qui brident toute velléité d'émancipation, soit pour maintenir sous les yeux la matière sensible de sa présence. Un même souci les rapproche dont l'expression les oppose. D'ailleurs, reprenant ce texte en 1960 à l'occasion d'une conférence, 
Claude Simon prend bien soin de souligner : «Foncièrement généreux, Sartre est obsédé par l'idée de servir, d'être utile, de donner. » Ce n'est pas l'homme qu'il vise mais une connaissance un peu plus avancée de ce qui fait la littérature.

Cet écart éclaire peut-être un pan de chacune des deux œuvres : l'une rend compte d'un acteur, inégal sans doute, mais ramenant ses contemporains vers la scène actuelle où ils font société ; l'autre affirme un témoin dont la pose aristocratique entend élever ses contemporains au sentiment électif de l'art. L'engagement sans cesse recommencé de Sartre s'oppose à celui toujours déçu de Simon.

Patrick LONGUET 